\title{
SPOR SPONSORLUĞUNDA SEKTÖREL YAKLAŞIMLAR
}

\section{Tamer KARADEMIR ${ }^{1}$ Sebahattin DEVECIOĞLU ${ }^{2} \quad$ Bilal ÇOBAN $^{3}$ Mahmut AÇAK ${ }^{4} \quad$ M. Emin KAFKAS ${ }^{5}$}

\section{ÖZET}

Sponsorluk bir olay ya da faaliyet için direk bir kuruluş yerine bir organizasyon tarafından bir olaya ya da faaliyete yönlendirilen kaynakların karşılanmasıdır. Sponsorluk aracılığı ile sporu kullanan şirket, markalar, dolaylı olarak reklam çalışmalarını gerçekleştirmektedirler. Sosyal anlamdaki spor pazarlaması için firmaların sporu kullanmak üzere sponsorluk yatırımında bulunmadığı görülür. Ancak bu alan için üretilecek toplumsal sosyal sorumluluk projeleri kurumların pazarlama hedefleri için çok etkin bir sahadır. Spor sponsorluğu büyük kitlelere hitap edebilmesi nedeniyle, özellikle ürünlerini ve hizmetlerini kısa zamanda bu kitlelere tanıtmak isteyen firmalarca yapılmaktadır.

Bu araştırmanın amacı; Türkiye de spor sponsorluğunda sektörel yaklaşımları tespit etmektir

Araştırmada; Veri toplama aracı olarak “anket yöntemi” kullanılmıştır. Anket 2007- 2008 yılında kendi illerinde kurumlar vergi sıralamasında ilk 100 e giren işletmeler arasından "tesadüfi örneklem" yolu ile seçilmiş toplam 109 işletmede gerçekleştirilmiştir.

Sonuç olarak; Spor sponsorluğuna "tekstil sektörü" nün ilgi gösterdiği, "otomotiv ve sağlık" sektörünün, sporda sponsorluğun "sosyal bir sorumluluk olduğu"nu "gıda ve akaryakı" sektörlerinin "ürünlerini tanıtımları" ile ilgili olarak, spor sponsorluğuna katılım sağladıkları, sponsor olarak "hedef kitlelerine ulaşım" sağlamada "gıda ve otomotiv" sektörlerinin ön plana çıktığı görülmüştür.

Anahtar Kelimeler: Spor, Sponsorluk, Sektör

\section{SECTORAL APPROACHES IN SPORTS SPONSORSHIP}

\section{ABSTRACT}

Sponsorship is to provide the resources diverted into an event or an activity by an organization instead of a direct institution for an event or an activity. The company which uses sports via the sponsorship realizes the brands and indirectly advertisement works. It is seen that the companies don't invest in the sponsorship for sports marketing socially to use sports. However, social responsibility projects that will be produced for this area is a very effective field for the marketing aims of the institutions. Sports sponsorship owing to appeal to the masses is done especially by the companies which want to introduce their products and services to these masses in a short time.

The purpose of this research; Turkey under the sponsorship of the sport is to identify sectoral approaches

In this Study 'survey method' is used as a means of data collection. The survey is carried out in total 109 business enterprises selected by the way of 'random sample' among those which are in the first 100 of the corporate tax ranking in their own cities in 2007 and 2008.

As a result, it is understood that 'textile sector' gives attention to sports sponsorship, 'automotive and health sectors' see the sponsorship in sports as 'a social responsibility', 'food and fuel' sectors participate in sports sponsorship concerning 'presentations of their products' and 'food and automotive' sectors come to the fore as a sponsor.

Key Words: Sports, sponsorship, sector

\footnotetext{
Kahramanmaraş Sütçü İmam Üniversitesi, Beden Eğitimi ve Spor Yüksekokulu, Kahramanmaraş

Fırat Üniversitesi, Beden Eğitimi ve Spor Yüksekokulu, Elazığ

Fırat Üniversitesi, Beden Eğitimi ve Spor Yüksekokulu, Elazığ

İnönü Üniversitesi, Beden Eğitimi ve Spor Yüksekokulu, Malatya

5 İnönü Üniversitesi, Beden Eğitimi ve Spor Yüksekokulu, Malatya
} 


\section{GíRiş}

Spor ve sportif etkinliklere gösterilen ilgi sadece insan sağlığı ve toplumsal ilişkilere değil, aynı zamanda ekonomik, sosyal ve siyasal hayata yaptığı katkıdan kaynaklanmaktadır. Bu nedenledir ki, birçok ülke spor ve sportif etkinliklerin gelişmesi için önemli düzeyde çaba harcamaktadır. Diğer taraftan sportif etkinliklerin her geçen gün daha geniş kitleler tarafından izlenmesi, onu kendi pazarını oluşturan bir sektör haline getirmiştir. Bu durum, sporla ilgili mal ve hizmet üreten işletme sayısının artması kadar, sporla doğrudan ilgisi olmayan işletmelerin de bu alana ilgi duymasına neden olmuştur. Birçok işletme, kendi şirketlerini ve markalarını geniş kitlelere tanıtmak için spor sponsorluğunu bir fırsat olarak görmeye başlamıştır (1).

Sponsorluk bir olay yada faaliyet için direk bir kuruluş yerine bir organizasyon tarafından bir olaya ya da faaliyete yönlendirilen (para, insan gücü, ekipman vb.) kaynakların karşılanmasıdır. Başka bir ifadeyle sponsorluk, yer ve zaman satın almaksızın işletme amaçlarına yönelik olarak kitle iletişim araçlarındaki gösteri ve olaylara yapılan yatırımlardır (2).

Genel anlamda sponsorluğun imaj transferi/imaj güçlendirmesi, imajı sürdürmesi, marka farkındalığını artırması, sosyal sorumluluk, marka farkındalığını sürdürmesi, yeni hedef kitleye ulaşılması, kurumsal kimlik ve çalışanları motive etmek gibi amaçları vardır (3).

Sponsorluğun iki unsuru vardır. Bunlar; Sponsor Arayan Firma ve Sponsor Firmadır. Sponsor arayan firma: Spor, sanat, toplumsal menfaat, çevre gibi birçok alanda faaliyet gösteren, etkinliği ispatlanmış, hedef kitlesi belli olan taraftır. Sponsor firma ise, bir bedel karşılığı yaratılmış etkinlikten veya bir uygulamadan yararlanan kurum veya bireydir (4). Spor bireysel ve toplumsal fayda açısından önemli mesafeler elde etmiştir.

Günümüzde her kuruluş benzer sponsorluk dalıyla, kuruluşun hedef kitlesine hitap edemeyeceğinden dolayı, önceden saptadığı hedeflere ve hedef kitleye ulaşmak için değişik sponsorluk alanlarını ve çeşitlerini tercih etmek durumundadır (5). Kuruluşların hizmet ve ürün çeşitlerine uygun seçecekleri sponsorluk uygulamaları kurumun tanıtımına önemli katkılar sağlayacaktır.

Başarılı bir sponsorluk faaliyetlerini gerçekleştirebilmek için, sponsor kuruluşun önceden belirlemiş olduğu hedeflerine ulaşabilmek amacıyla sponsorluk yapacağı alanın planlamasını ve uygulamasını yaparak, hedef kitleye vermek istediği mesajları diğer iletişim araçlarının da yardımlarıyla göndermesi ve yapılan sponsorluk faaliyetinden elde edilecek sonuçların ancak uzun vadede gerçekleştirilebileceğini göz önünde bulundurulması gerekmektedir (6).

Benimsenen ekonomik politikalar sonucu, giderek güç kazanan işletmelerin ekonomik hayattaki rolünün artması, onların sporun gelişmesine son derece önemli katkılar sağlayabileceğini göstermektedir. Ancak, işletmelerin bu katkıyı sağlaması ticari kazanç elde edebilmelerine bağlıdır (7). Diğer bir ifadeyle sporda sponsorluğunun gelişmesi, sponsor firmaların kısa veya uzun dönemde tüketiciler tarafından ödüllendirilmesine bağlıdır. Bu nedenle sponsorluğun tüketicilerin satın alma kararlarını ne ölçüde etkilediğinin bilinmesi son derece önemlidir (8).

Sponsorluk kavramı değişik platformlarda uygulama alanı bulmuştur. Hızla gelişen iletişim teknolojisi, işletmeleri hedef kitlelerine ulaşmak için sponsor olma eğilimine sokmuştur. Marketing Surveys tarafından 2004 yılında yapılan araştırmada sponsorluğun sektörel dağılımı Şekil 1 de gösterilmiştir.

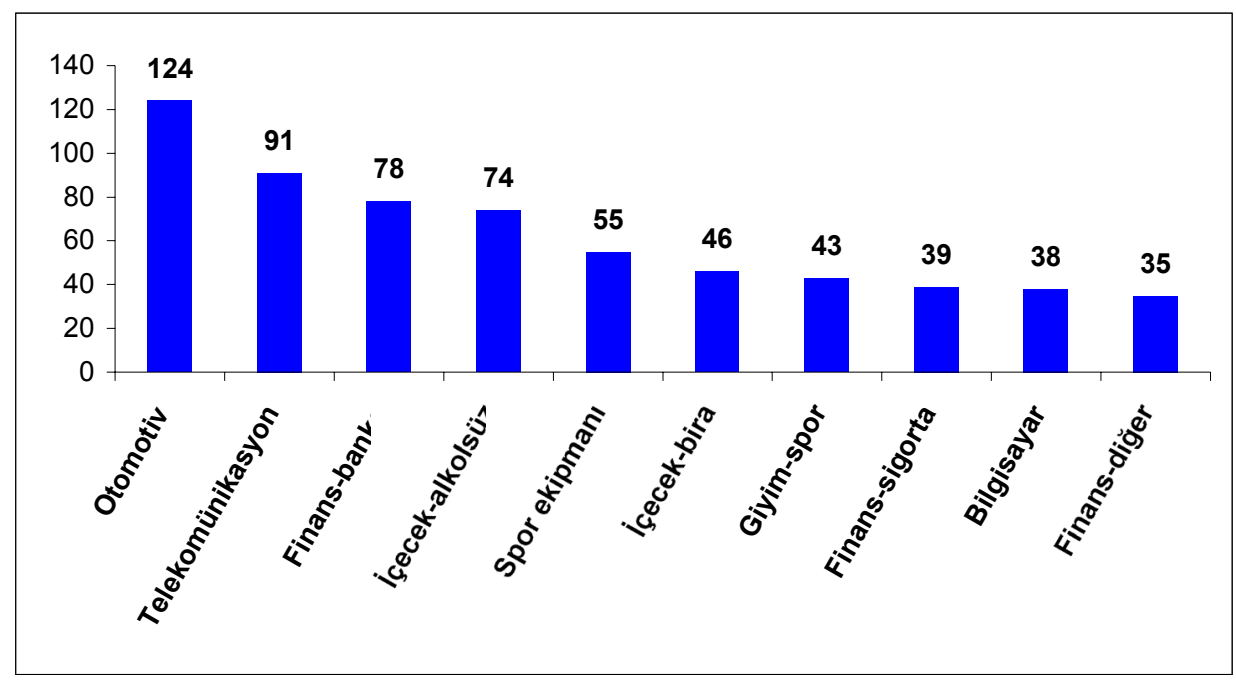

Kaynak: Marketing Surveys 2004

Şekil 1. Sponsorluğun Sektörel Dağılımı 
Sponsorluk uygulamaları içerisinde bütün dünya ülkelerinde spor sponsorluğu, işletmeler (kişi ve kurumlar) bakımından daha bir cazibe merkezi haline gelmiştir. Spor, sponsorluk harcamaları içerisinde sahip olduğu \% 69 'luk oran ile bu alanda öncülük yapmaktadır (9). Spor sponsorluğu sponsorluk türleri arasında en geniş yeri alan sponsorluk türüdür (Şekil 2.).

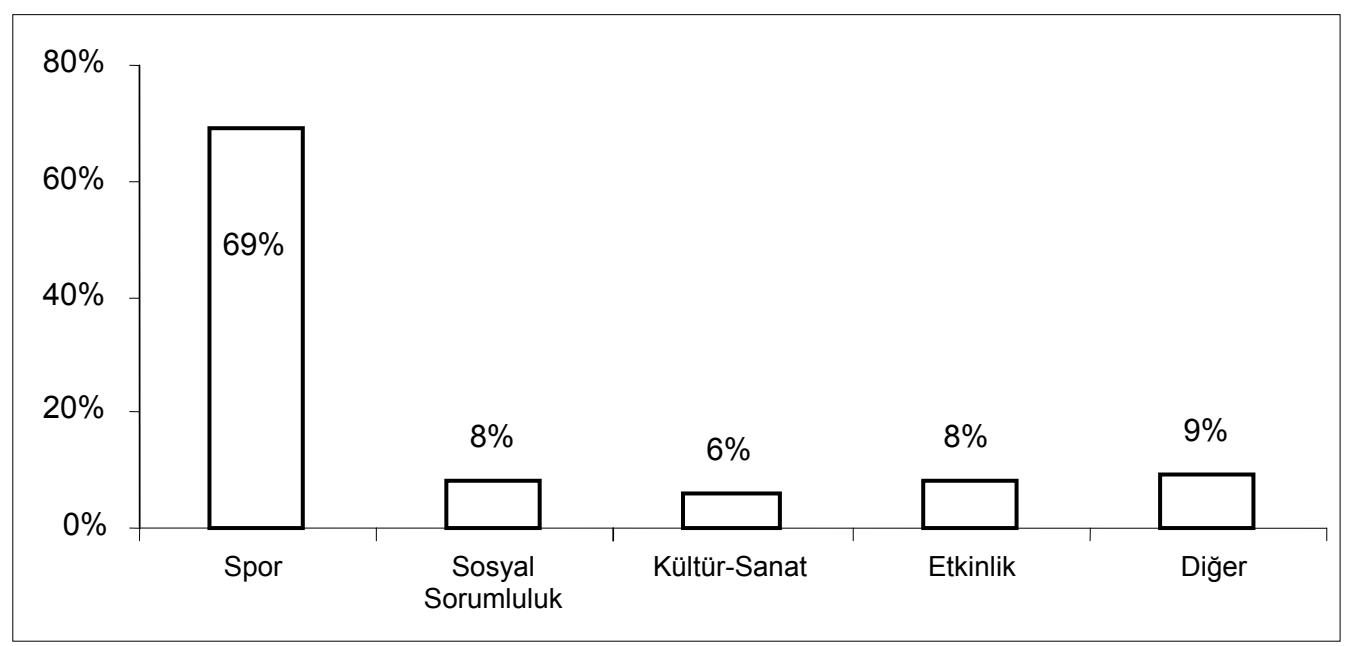

Kaynak: Sponsorluk Bülteni, Sayı 1, 2002, s. 1

\section{Şekil 2. Sponsorluk Türlerinin Dağılımı}

Spor sponsorluğu büyük kitlelere hitap edebilmesi nedeniyle, özellikle ürünlerini ve hizmetlerini kısa zamanda bu kitlelere tanıtmak isteyen firmalarca yapılmaktadır. Çünkü spor, hedef kitleyle iletişim kurma olanağı sağlayan ve hemen hemen bütün dünyada anlaşılan, aynı dili konuşan bir sponsorluk alanıdır (6). Spor sponsorluğunun tercih edilmesinin nedenleri arasında reklam maliyetinin artması, sigara ve alkol ürünlerine yönelik reklam yasağı gibi bir takım faktörlerde yer almaktadır $(10,11)$.

Türkiye de Profesyonel ve amatör spor dallarının ulusal ve uluslararası yarışma ve maçlarda daha başarılı olması, yeni spor dallarının daha fazla desteklenmesi ve geliştirilmesi amacıyla ulusal spor kulüplerimizin ve milli takımlarımızın desteklenmesi amacıyla yapılacak sponsorluk harcamaları yasal düzenlemeler ile harcamaları yapanlara Gelir ve Kurumlar Vergisi istisnası sağlamıştır. İstisnadan faydalanılması ve uygulanmasına ilişkin olarak, 5105 sayılı Kanunla GVK nun 89 ncu maddesine eklenen 8 nci fıkra hükmü uyarınca, 3289 sayılı Gençlik ve Spor Genel Müdürlüğü Teşkilat ve Görevleri Hakkındaki Kanun ile 17.06.1992 tarihli ve 3813 sayılı Türkiye Futbol Federasyonu kuruluş ve görevleri hakkında Kanun ve Gençlik ve Spor Genel Müdürlüğü tarafından 16.06.2004 tarih ve 25494 sayılı Resmi Gazetede yayımlanan Sponsorluk Yönetmeliği gerekli düzenlemeleri yapmıştır. Gelir ve Kurumlar Vergisinde, yapılan harcama tutarının istisnaya tabi olacağı hükme bağlanmıştır (12).

Sponsorluk aracılığı ile sporu kullanan şirket, markalar, dolaylı olarak reklam çalışmalarını gerçekleştirmektedirler. Sosyal anlamdaki spor pazarlaması için firmaların sporu kullanmak üzere sponsorluk yatırımında bulunmadığı görülür. Ancak bu alan için üretilecek toplumsal sosyal sorumluluk projeleri kurumların pazarlama hedefleri için çok etkin bir sahadır. Spor sponsorluğu büyük kitlelere hitap edebilmesi nedeniyle, özellikle ürünlerini ve hizmetlerini kısa zamanda bu kitlelere tanıtmak isteyen firmalarca yapılmaktadır.

Türkiye'de spor sponsorluğunda sektörel yaklaşımları tespit etmeye yönelik değerlendirilen araştırma, spor sponsorluğuna sektörlerin ön plana çıkan yaklaşımları bundan sonra yapılacak olan spor sponsorluğu uygulamaları açısından önem arz etmektedir.

\section{MATERYAL VE YÖNTEM}

Araştırma 2007- 2008 yılında kendi illerinde kurumlar vergi sıralamasında ilk 100 e giren işletmeler arasından "tesadüfî örneklem" yolu ile seçilmiş toplam 109 işletmede gerçekleştirilmiştir.

Araştırmada; Veri toplama aracı olarak "anket yöntemi” kullanılmıştır. Anket araştırmacı tarafından sponsorluk alanında yapılmış önceki araştırmalar dikkate alınarak geliştirilerek araştırma konusu ile ilgili sorulardan oluşturulmuştur. Anketin genel güvenirliği için yapılan analizde, Cronbach-Alpha iç tutarlılık katsayılarına bakılmış ve sonucun 0.73 bulunması, ankete verilen cevaplardan elde edilen verilerin, değerlendirme için uygun olduğu sonucuna varılmıştır. Anket sorularını değerlendirmek için 5 'li likert tipi derecelendirme kullanılmıştır. Tamamen katılıyorum (5 puan)- kesinlikle 
katılmıyorum (1 puan) aralığında değer verilmiştir. Puanların artması sorulara verilen cevabın kendileri için uygunluğuna işaret etmektedir.

Araştırma için anketler işletmelere elektronik posta yoluyla gönderilmiştir. Ankete işletmelerin sahibi veya işletme ile ilgili karar yetkisine sahip kişiler tarafından cevap verilmesine özen gösterilmiştir..

Ankete verilen cevaplardan elde edilen veriler SPSS 15,0 paket programına yüklenmiş ve sektörel dağılımın "frekans ve yüzdelik" hesapları yapılmıştır. Araştırma kapsamında sektörlerin ankete verdikleri cevapların aritmetik ortalamaları üzerinden "spor sponsorluğu" hakkındaki görüş ve değerlendirmeleri ortaya konulmuştur.

\section{BULGULAR}

Araştırma kapsamında yer alan sektörlerin dağılım oranları ve spor sponsorluğuna yaklaşım ve değerlendirmeleri ile ilgili veriler tablolar halinde sunulmuştur

Tablo 1. Sektörel Dağılımda Tanımlayıcılar

\begin{tabular}{|l|c|c|}
\hline \multicolumn{1}{|c|}{ Sektörler } & f & \% \\
\hline Tekstil & 36 & 33.0 \\
\hline Gıda & 11 & 10.1 \\
\hline Akaryakıt & 10 & 9.2 \\
\hline Sağlık & 18 & 16.5 \\
\hline Endüstriyel & 20 & 18.4 \\
\hline Otomotiv & 12 & 11.0 \\
\hline İletişim & 2 & 1.8 \\
\hline Toplam & $\mathbf{1 0 9}$ & $\mathbf{1 0 0 . 0}$ \\
\hline
\end{tabular}

Tablo 1' de Araştırmaya alınan sektörler içerisinde en yüksek oranı \%33,0 "tekstil sektörü", en az \% 1,8 oranında ise "iletişim sektörü" oluşturmaktadır.

Tablo 2. Sektörlerin Ürün Tanıtımında Spor Sponsorluğuna Yaklaşımlarının Dağılımları

\begin{tabular}{|l|c|c|c|c|}
\hline Sektörler & $\mathbf{f}$ & $\overline{\mathbf{X}}$ & $\mathbf{S d \pm}$ & \% \\
\hline Tekstil & 36 & 38.2222 & 3.33904 & 33.0 \\
\hline Gıda & 11 & 39.5455 & 3.50325 & 10.1 \\
\hline Akaryakıt & 10 & 39.5000 & 3.65908 & 9.2 \\
\hline Sağlık & 18 & 38.3333 & 4.28403 & 16.5 \\
\hline Endüstriyel & 20 & 38.3000 & 2.92179 & 18.4 \\
\hline Otomotiv & 12 & 38.9167 & 4.87029 & 11.0 \\
\hline İletişim & 2 & 33.0000 & 4.24264 & 1.8 \\
\hline Toplam & $\mathbf{1 0 9}$ & $\mathbf{3 8 . 4 8 6 2}$ & $\mathbf{3 . 6 9 5 8 8}$ & $\mathbf{1 0 0 . 0}$ \\
\hline
\end{tabular}

Tablo 2'de Sektörlerin ürünlerini tanıtımları ile ilgili olarak, spor sponsorluğuna katılımın uygunluğunda; "gıda $(39.545 \pm 3.50)$ ve akaryakıt $(39.500 \pm 3.65)$ " sektörünün en fazla puan, "iletişim sektörünün $(33.000 \pm 4.242)$ " ise en az puan alan sektör olduğu görülmektedir.

Tablo 3. Sektörlerin Sosyal Sorumluluk Anlayışında Spor Sponsorluğuna Yaklaşımlarının Dağılımları

\begin{tabular}{|l|c|c|c|c|} 
Sektörler & $\mathbf{f}$ & $\overline{\mathbf{X}}$ & $\mathbf{S d} \mathbf{\pm}$ & $\mathbf{\%}$ \\
\hline Tekstil & 36 & 19.2500 & 2.27251 & 33.0 \\
\hline Gıda & 11 & 20.0000 & 3.28634 & 10.1 \\
\hline Akaryakıt & 10 & 20.2000 & 2.61619 & 9.2 \\
\hline Sağlık & 18 & 20.2778 & 2.24409 & 16.5 \\
\hline Endüstriyel & 20 & 18.9500 & 2.18789 & 18.4 \\
\hline Otomotiv & 12 & 20.3333 & 2.34844 & 11.0 \\
\hline İletişim & 2 & 18.5000 & 2.12132 & 1.8 \\
\hline Toplam & $\mathbf{1 0 9}$ & $\mathbf{1 9 . 6 3 3 0}$ & $\mathbf{2 . 4 1 0 0 9}$ & $\mathbf{1 0 0 . 0}$ \\
\hline
\end{tabular}


Tablo 3' de Sporda sponsorluğun "sosyal bir sorumluluk olduğu" görüşünde, sektörler içerisinde en fazla puan alan "otomotiv $(20.333 \pm 2.348)$ ve sağlık $(20.277 \pm 2.244)$ ", en az puan alan "iletişim $(18.500 \pm 2.121)$ ve endüstriyel $(18.950 \pm 2.187)$ " sektörü olarak görülmektedir.

Tablo 4. Sektörlerin Hedef Kitleye Ulaşmada Spor Sponsorluğuna Yaklaşımlarının Dağılımları

\begin{tabular}{|l|c|c|c|c|}
\hline Sektörler & $\mathbf{f}$ & $\overline{\mathbf{X}}$ & $\mathbf{S d} \mathbf{\pm}$ & $\boldsymbol{\%}$ \\
\hline Tekstil & 36 & 31.1111 & 2.64875 & 33.0 \\
\hline Gıda & 11 & 32.8182 & 3.51620 & 10.1 \\
\hline Akaryakıt & 10 & 32.1000 & 4.17532 & 9.2 \\
\hline Sağık & 18 & 31.3333 & 3.86538 & 16.5 \\
\hline Endüstriyel & 20 & 31.3000 & 3.21346 & 18.4 \\
\hline Otomotiv & 12 & 32.6667 & 1.96946 & 11.0 \\
\hline Illetişim & 2 & 28.0000 & 1.41421 & 1.8 \\
\hline Toplam & $\mathbf{1 0 9}$ & $\mathbf{3 1 . 5 5 9 6}$ & $\mathbf{3 . 1 7 8 1 4}$ & $\mathbf{1 0 0 . 0}$ \\
\hline
\end{tabular}

Tablo 4' de Sektörlerin "hedef kitlelerine ulaşım" değerlendirmelerinde en fazla puanı "gıda (32.818 \pm 3.516$)$ ve otomotiv (32.666 \pm 1.969$)$ ", en az puanı ise "iletişim $(28.000 \pm 1.414)$ ve tekstil $(31.111 \pm 2.648)$ " sektörü almıştır .

\section{TARTIŞMA VE SONUÇ}

Spor sponsorluğu uygulamalarında çeşitli sektörler yer almakla birlikte, spor sponsorluğu içerisinde yer alan sektörlerin farklı olması sponsorluk uygulamalarının yerine zamanına ve organizasyonun şekline göre değiştiği birçok araştırmada görülmektedir.

2008-2009 sezonunda 100'den fazla firmanın Turkcell Süper Lig'de mücadele eden 18 kulübe sponsor olduğu, yaklaşık 20 sektörde faaliyet gösteren bu firmalar sadece büyük kulüplere değil Anadolu'nun çeşitli bölgelerindeki kulüplere de destek verdiği, Futbola en çok yatırım yapan sektörlerin başında gıda, içecek, turizm, telekomünikasyon ve hazır giyim markaları gelirken bu anlaşmaların çoğunun teknik ve tedarik sponsorluğu olarak geçtiği vurgulanmaktadır (13).

Araştırmaya alınan sektörler içerisinde en yüksek oranı \%33,0 "tekstil sektörü", en az \% 1,8 oranında ise "iletişim sektörü" oluşturmaktadır.

Sponsorluk, işletmelerin olağan aktivitelerinin doğrudan bir bölümü olmayan, işletmelerin imajını geliştirmek, markaların tanınırlığını artırmak ya da doğrudan ürünlerin/hizmetlerinin pazarlanmasını sağlamak için ticari yararlar elde edebileceği faaliyetlere/olaylara finansal ve materyal desteği sağlayan ticari bir yatırımdır (14).

Araştırmada; Sektörlerin ürünlerini tanıtımları ile ilgili olarak, spor sponsorluğuna katılımın uygunluğunda; "gıda (39.545 \pm 3.50$)$ ve akaryakıt $(39.500 \pm 3.65)$ " sektörünün en fazla puan, "iletişim sektörünün $(33.000 \pm 4.242)$ " ise en az puan alan sektör olduğu görülmektedir. Ortalama toplam puan $(38,486 \pm 3,695)$ açısından bakıldığında bu oranın sektörel yaklaşımlar açısından (sporun/olay) ürün tanıımı için kabul gördüğü yönündedir ( Tablo 2.).

İşletmeler, bir ürünü ile veya ürün hattı ile sponsorluk yapabilir. Burada ürünün kendisi ile sporun/olayın birbirine uyumu önemli bir konudur. Her spor olayı, her ürün için uygun etki sağlamayabilir. İşletmeler için uygun sporu/olayı bulmanın en önemli kuralı, sponsorun ürünlerini satmaları insanların yani hedef kitlenin özellikleri ile ürünün hedef kitle özelliklerinin birbirini desteklemesidir. Pek çok olay yöneticisi, olaylarından hoşlanan kişilerin özelliklerini belirlemiştir ve bu konuda sponsorlara bilgi kaynağı sağlamaktadır. Bu kaynakları edinen potansiyel sponsorlar hangi sporun kendi ürünleri için uygun olduğunu bulabilir (15). Örneğin, bir tenis turnuvasında Puma Firmasının spor malzemeleri üreticisinin raketleri ile sponsorluğa iştirak etmesi olay ile çok iyi örtüşmektedir. Olay sonrası Puma' Firmasının tenis raketi satışlarında bir artış olduğu görülmüştür. Aynı şekilde Orkid firmasının Türkiye bayan voleybol milli takımına sponsorluk yapması da gösterilebilir.

Organizasyonlarda veya spor yerinde reklam panolarının veya sponsorlara ilişkin işaret, simge veya marka adlarının uygun şekilde yerleştirilmesi mesajın algılanmasını etkileyebilmektedir. Ayrıca bilimsel araştırmalara göre de ürünle etkinlik arasında uyum"un yüksek olması tüketicilerin marka/ürüne verdikleri reaksiyonu etkilemektedir $(16,17)$.

İşletmeleri spor sponsorluğunu seçmeye yönelten faktörlerin içerisinde toplum onayını kazanma fırsatı, ürün ve hizmetlerin farkına varımasını sağlama, uygun medya ilgisi ve tanıtım yaratmadır. Bütün bu nedenlere bağlı olarak günümüzde işletmeler artan vizyonları sayesinde, ürün ve hizmetlerin spor sponsorluğu yoluyla pazarlanması tahmin edildiği gibi ürün ve hizmetin tüketimini de arttırmıştır (11). 
Araştırmada; Sporda sponsorluğun "sosyal bir sorumluluk olduğu" görüşünde, sektörler içerisinde en fazla puan alan "otomotiv $(20.333 \pm 2.348)$ ve sağlık $(20.277 \pm 2.244)$ ", en az puan alan "iletişim $(18.500 \pm 2.121)$ ve endüstriyel $(18.950 \pm 2.187)$ " sektörü olarak görülmektedir. Ortalama toplam puan $(19,633 \pm 2,410)$ açısından bakıldığında bu oranın sektörel yaklaşımlar açısından (sporun/olay) sosyal bir sorumluluk olarak değerlendirilmesi gerektiği görüşünü destekledikleri söylenebilir ( Tablo 3.).

İşletmelerin halkla ilişkiler faaliyetlerinde kullanılması açısından sponsorluk çok uygun bir faaliyettir. Çünkü sponsorluk yapan kuruluş topluma karşı olan sorumluluğunu, kendisinin yönlendirmediği bir faaliyeti desteklemekle hem topluma hizmet etmekte, hem de kuruluş imajının gelişmesine katkıda bulunmaktadır. Sponsorluk ve halkla ilişkiler faaliyetinin tespit edilmesi ve seçilen alanlarda faaliyette bulunulmasına karar verilmesinde, toplumun ihtiyaçlarının karşılanması düşüncesi de yer alarak kuruluşların sosyal yükümlülükleri ön plana çıkmaktadır (4). Bunda işletme hakkında pozitif duyguların oluşmasında, sosyal sponsorluk alanında uygulamış oldukları faaliyetlerin, halk tarafından desteklenmesinin önemli bir etkisi vardır. Sponsorluğun algılamaya yönelik hedeflerine ulaşmada, önemli rol oynayan faktörler arasında, hayırseverlik ve bağış gibi görünen sosyal sponsorluk faaliyetleri de bulunmaktadır (5).

Tüketiciler çok sayıdaki işletmelerin benzer ürünleri arasında, şirketlere ürettikleri ürünlerden daha çok topluma kattıkları pozitif değerler ile bakmaya başlamışlardır. Bu değerlerde ön plana çıkan, sosyal sorumluluğun temelinde olan 'topluma geri verme' ilkesi ve şirketlerin topluma ve çalışanlarına karşı olan saygısını ifade eden sosyal sorumluluk tutum ve davranışlarıdır. Amerika'da yapılan bir araştırmaya göre; "Eğer kalite ve fiyat farkı yoksa, dünya için iyi şeyler yaptığına inandığı ve sosyal sorumluluk taşıyan şirketin ürününü tercih ederim” diyenlerin oranı son üç yılda yüzde 55 'ten yüzde 65'e çıkmıştır. Ünlü üretim gurubu Peter Drucker ise "geçtiğimiz 40-50 yılda ekonomik faktörler dominanttı, bundan sonraki 20-30 yılda ise, sosyal faktörler dominant olacaktır." demekle, kalkınmanın ivme kazanması, özel sektör ve sivil toplum işbirliği ile mümkün olacağını ortaya koymaktadır (18).

Baş'ın (2008) yapmış olduğu çalışmada da federasyonların sponsor seçimindeki kriterlerinin önem derecelerinde 1. sırayı verdikleri para miktarı, 2. derecede misyon/vizyon, 3. derecede tanınmışlık ve sonrasında sosyal sorumluluk sahibi olması gösterilmiştir. Bu sıralama içerisinde sosyal sorumluk sahibi olma derecesini \%35.1 oranında fark etmez, \%49.1 oranında önemli ve \%15.8 oranında çok önemli olarak değerlendirmişlerdir (19).

Araştırmada; Sektörlerin "hedef kitlelerine ulaşım" değerlendirmelerinde en fazla puanı "gıda $(32.818 \pm 3.516)$ ve otomotiv (32.666 \pm 1.969$)$ ", en az puanı ise "iletişim $(28.000 \pm 1.414)$ ve tekstil $(31.111 \pm 2.648)$ " sektörü almıştır. Ortalama toplam puan $(31,559 \pm 3,178)$ açısından bakıldığında bu oranın sektörel yaklaşımlar açısından (sporun/olay) hedef kitleye ulaşımda önemli bir kaynak olarak değer bulduğu ifade edilebilir ( Tablo 4.).

Hedef kitle ile farklı yollardan ilişki kurmak, marka imajlarını geliştirmek ve farkındalığı yükseltmeyi arzulayan kurumlar spor sponsorluğunu değerlendirerek yararlar elde edebilir. Sponsorluğun yararlı olabilmesi, her şeyden önce kavramın ve yönetim sürecinin iyi anlaşılmasına bağlıdır. Çünkü sponsorluk planlama sürecinde göz önüne alınması gereken etmenlerden biri de hedef kitlenin belirlenmesidir (20). Hedef kitlesi genel kamuoyu olan sponsorluk için, hedef kitle özelliklerinin tanımına daha az gereksinim olmaktadır. Bu yönde hedef belirlenen sponsorluğun nedeni, geniş bir tüketici ya da tüketici yelpazesine sahip olma durumudur. Bu da sponsorluk farkındalığının ve sponsorluk yapılan etkinlikle birlikte şirket ya da ürün adının etkili biçimde işleme olasılığının önemini arttırır.

Spor sponsorluğunda hedef kitle, mevcut ve potansiyel tüketicilerdir. Spor sponsorluğunda tüketici hedef kitlesi, spor olayı katılımcıları, olay yerindeki seyirciler veya medya aracılığı ile olayı izleyen seyircilerdir. Sponsorluk doğrudan ürün tüketicisine yönelik olabilir. Hedef kitle ürün tüketicisi olduğundan sponsorluğun bu kitleye uygun olması gerekir. Araştırma yapılmadıkça, seçilen sponsorluğun mevcut ya da potansiyel tüketici kitleye uygun olmama riski her zaman yüksektir. İşletmeler sponsorluk faaliyeti için çeşitli seyirci grubuna sahip olabilir. Belli bir hedef seyircisine uygun sponsorluk programının ele alınması önemli bir faktördür. Özel hedef kitleye uygun sponsorluk programı oluşturmak için hedef kitlenin demografik, coğrafik, yaşam stili, psikografik faktörlerle ilgili bilgilerin bilinmesi gerekmektedir (21).

Bir tutundurma aracı olarak spor sponsorluğun önemli özelliklerinden birisi, genel bir ilgiyi paylaştıkları için spor platformundan etkilenen insanlara ulaşma kabiliyetidir. Bu nedenle spor olayları tüketicilerin psikografik bölümlenmesi için doğal bir fırsat sunar. Spor sponsorluğu, tüketicilere yaşadıkları yerlerde ulaşma imkanı sağlar. Etkili bir şekilde kullanıldığında tüketicilere geleneksel reklamdan daha etkili ulaşır (22).

Araştırmada sonuç olarak; Spor sponsorluğuna "tekstil sektörü" nün ilgi gösterdiği, "otomotiv ve sağlık" sektörünün, sporda sponsorluğun "sosyal bir sorumluluk olduğu"nu "gıda ve akaryakıt" sektörlerinin "ürünlerini tanıtımları" ile ilgili olarak, spor sponsorluğuna katılım sağladıkları, sponsor olarak "hedef kitlelerine ulaşım" sağlamada "gıda ve otomotiv" sektörlerinin ön plana çıktığı görülmüştür.

Sponsorları spor alanına yönelten sebeplerin arasında, sporun hedef kitlelere daha kolay ulaşması ve kitle iletişim araçlarının da spor olaylarına çokça yer vermesinin olduğu söylenebilir. İyi planlanmış ve etüt edilmiş bir sponsorluk faaliyeti hedef kitle üzerinde oldukça fazla bir etki sağlayacağından dolayı hem işletme hem de ürün üzerinde yüksek bir farkındalığı oluşturabilecektir. Burada göz önünde bulundurulması gereken hedef kitlenin çok iyi belirlenmesi ve buna yönelik olarak planlamanın etkili olabilmesi için gerektiğinde uzman kişilerden destek alınarak yapılmasıdır. 


\section{KAYNAKLAR}

1. Nicholls, J.A.F.,Roslow S., "Brand Recall and Brand preference at sponsored golf and tennis tournaments" Europen Journal of Marketing, Vol.33, No.3/4, pp.365-386,1999.

2. Karadeniz,M., "Pazarlama İletişimi Kapsamında Sponsorluk Faaliyetlerinin Önemi” Journal of Naval Science and Engineering, Vol. 5 , No.1, pp. 62-75,2009.

3. Roy, D. P., Cornwell, T. B., "The Effects of Consumer Knowledge on Responses to Event Sponsorships", Psychology \& Marketing, 21 (3), 2004.

4. Budak, G. ve Budak, G., Halkla İlişkiler, 4. Baskı, İzmir:Barış Yayınları, s.233,2004.

5. Aydemir, O., Halkla İlişkiler,2. Basım, Der Yayınevi, s.440-444, İstanbul, 2005.

6. Aydemir, O., Halkla İlişkiler Aracı Olarak Sponsorluk, Epsilon Yayıncılık, İstanbul, 1998.

7. Slatter, J.,Lloyd,C., "It's gotta be the Shoes: Exploring the effect of relationship of the Nike and Reebok Sponsorship on two college athletic programs, Sport marketing and the Psychology of marketing Communication ,pp.191-210, 2003.

8. Akyıldız,M., Marangoz, M.,"Sporda Sponsorluğun Tüketicilerin Satın alma Niyetine Yansıması”, Ege Akademik Bakış / Ege Academic Review 8 (1), 153-166,2008.

9. Stotlar, D.K., "Sponsorship Evaluation: Moving From Theory To Practice", Sport Marketing Quarterly. 13, 61-64, 2004

10. Ekenci,G., İmamoğlu,A.,F., Spor İşletmeciliği, Alp Ofset, ANKARA, 1998.

11. Mccook, K., Turco, D., And Rıley, R., "A Look at the Corporate Sponsorship Decision Making Process", The Cyber- Journal of Sport Marketing. Volume 1, Number 2, April 1997.

12. Ilız,F.,SponsorlukHarcamaları,: http://www.gurselerkulilizymm.com/makaleler/sponsorluk_harcamaları.pdf Erişim Tarihi; 02 12,2009

13. http://www.haberler.com/futbolda-sponsorlar-yarisa-girdi-haberi/ 8 Temmuz 2009

14. Javalgi, R., Mark, B.,Andrew, C. ve Edward L., "Awareness of Sponsorship and Corporate Image: An Empirical Investigation”, Journal of Advertising, December, V:XXIII, N:4, 1994.

15. Schreüber, A. L., "Your Big Event: Checklist to Prevent A Disaster", Public Relation Quarterly, Volume 36, Issue 3, s. $20-21.1991$.

16. Pham, M.T. ve Johar, G.V., "Market Prominence Biases in Sponsor Identification: Processes and Consequentiality", Psychology and Marketing, 18, 2, 123-143, 2001.

17. Speed, R., ve Thompson, P., "Determinants of Sports Sponsorship Response”, Journal of The Academy of Marketing Science, 28, 2, 226-238,2000.

18. Tezcan, K., Sponsorluk harcamalarının önemi ve vergisel boyutu, mali çözüm íSMMMO yayın organı, s.78, $103,2006$.

19. Baş, M., "Spor Sponsorluğu ve Spor Federasyonlarının Sponsorluğa Bakışı Üzerine Bir Araştırma”, Gazi Üniversitesi İktisadi ve İdari Bilimler Fakültesi Dergisi, 10 / 3 . 111-124, 2008.

20. Akyürek, R., Sponsorluk Planlaması. Anadolu Üniversitesi, Eğitim, Sağlık ve Bilimsel Araştırma Vakfı Yay. No: 135. Eskişehir, 1998.

21. Meenaghan, T., "The Role of Sponsorship in the Marketing Communications Mix", International Journal of Advertising. Volume 10, Number 1, 1991.

22. Shank, M. D., Sports Marketing, A Strategic Perspective. Prentice Hail, New Jersey, 1999. 